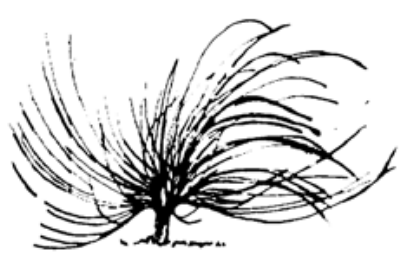

\title{
Workshop: Training for the Teachers of English at CEIC, in Alajuela, on Web 2.0 Tools that Can Be Used with their Students in Order to Promote the Use of English Outside of the Classroom, Focusing on the Oral Production (Speaking Skill)
}

\author{
Johnny Antonio Mora González ${ }^{1}$ \\ Universidad Nacional \\ Alajuela, Costa Rica \\ jamoragon@hotmail.es
}

\begin{abstract}
This article reports on the findings of research carried out to analyze the methodology and prior knowledge on Web 2.0 of the teachers at Centro de Estudios en Inglés Conversacional (CEIC) in Alajuela in order to design and implement a workshop on Web 2.0 tools to train them so that they could promote the use of the speaking skill outside the class with their students. To collect data, three instruments were used, a questionnaire to determine the methodology and previous knowledge of the teacher, a second questionnaire to assess the workshop, facilitator and outcomes of the workshop, and a final questionnaire for the teacher to carry out a SWOT analysis of three
\end{abstract}

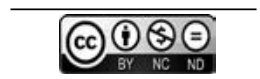

Recibido: 2 de mayo de 2016-Aprobado: 22 de setiembre de 2016

1 Profesor de inglés, Centro de Estudios en Inglés Conversacional, Universidad Nacional. Master en Educación con énfasis en el Aprendizaje del Inglés y Bachiller en Enseñanza del Inglés, ambos títulos obtenidos en la Universidad Nacional. 
oral tasks created using Web 2.0 tools. The data collected were analyzed based on predetermined categories of analysis. In general, the findings obtained point to the fact that teachers are willing to implement and find the use of Web 2.0 tools helpful when aiming to promote the use of the speaking skill outside the classes.

Keywords: Web 2.0 tools, speaking skill, teachers, workshop, training, TELL, Connectivism, SMLL

\section{Resumen}

Este artículo presenta los resultados de una investigación llevada a cabo para analizar la metodología y el conocimiento previo de herramientas Web 2.0 del profesorado del Centro de Estudios en Inglés Conversacional (CEIC) en Alajuela, con el fin de diseñar e implementar un taller sobre el uso de herramientas Web 2.0 para que este pueda promover el uso de la habilidad del habla fuera de clases con sus estudiantes. Para recopilar los datos, se utilizaron tres instrumentos, un cuestionario para determinar la metodología y conocimiento previo de herramientas Web 2.0 de docentes, un segundo cuestionario a para evaluar el taller, el facilitador y resultados del taller, y un último cuestionario para que el profesorado realizara un análisis FODA de tres tareas orales creadas incluyendo las herramientas Web 2.0. Los datos se analizaron con base en las categorías de análisis. En general, los hallazgos obtenidos confirman el hecho de que el personal docente está dispuestoque a implementar y encuentra el uso de las herramientas Web 2.0 útiles para promover el uso de la habilidad del habla fuera de clases.

Palabras clave: Herramientas Web 2.0, habilidad de habla, profesorado, taller, capacitación, TELL, conectivismo, SMLL.

\section{Introduction}

This research problem studied arose from the fact that teachers at Centro de Estudios en Inglés Conversacional (CEIC) are not using 
strategies that may make their students use English orally out of classes. Throughout the development of classes, teachers can make sure that students interact with their peers and teachers, whereas when working out of the classroom, they have more difficulty making students use the target language. Implementation of traditional types of homework such as the use of the workbook does not match the way English is usually used in the classroom. That is, there is use of technology in the classes of conversational courses through the use of the language laboratory; still, this could be well complemented by the use of technological tools that teachers can implement to strengthen or assign work outside the classroom that is more in line with what takes place in the classroom.

It is clear that homework or performing work outside the classroom is carried out in a very traditional way. For example, one of the tasks that better exemplifies this problem is that the teachers assign pages from the textbook as homework. Even when these activities might serve as practice, it is inconsistent with the nature of the courses themselves, which is conversational. As part of the context for this problem, it can be mentioned that sometimes the online complement of the book is used to assign homework as well. However, this supplement of the book is a website for the students to visit and conduct practical exercises on the material studied in class. The site also allows students to print or save a document with the amount of exercises that the student completed. However, while these exercises can be interactive, these activities are only a reproduction of the activities presented in the workbook which are basically exercises of completion, fill in the blanks, matching, and so forth.

Also, the teacher is not able to give feedback to students as there is no way to see what needs students may have. Besides, the use of the website is not helpful to the needs of the students since there are no exercises of oral production on the website that might be helpful for the students to practice the language orally outside of the classroom.

All these situations point to the fact that most teachers are not being able to promote the oral production of English outside the classroom just as they do so in the classroom. They could do so if they had the appropriate tools to facilitate this goal. Hence, it is important for teachers at CEIC Alajuela to start to acquire knowledge regarding resources that can be used in order for their students to also practice the speaking skill outside the classroom. 
As a result, the following research question was stated: How can teachers at CEIC, in Alajuela, be trained to use web 2.0 tools to promote their students' oral production (Speaking skill) out of the classroom and meet the learning needs of the students in the conversational program?

Hence, the main goal of this research was to design and develop a workshop about three Web 2.0 tools for teachers at Centro de Estudios en Inglés Conversacional (CEIC) in Alajuela, to promote the use of the speaking skill outside of class and meet the learning needs of the students in the conversational program. Therefore, the specific objectives proposed were: first, to identify the previous knowledge of Web 2.0 tools that teachers at CEIC in Alajuela had; second, to design and implement a workshop about three Web 2.0 tools so teachers are able to promote the use of the speaking skill outside of class; and third, to assess the workshop that they were part of.

\section{Exploratory Diagnosis}

Stepp-Greany (2002) explained what perceptions students have in regards to the use of technology in the language learning classroom. Also, Stepp-Greany (2002) focused on how important the role of the teacher is in the approach Technology-Enhanced Language Learning (TELL). Finally, the Stepp-Greany (2002) made reference to the effects that the use of technology might have in the process of foreign language learning. Indeed, there are indicators that show that the use technology in the classroom can be beneficial when teaching English. Villalba (2007-2008) mentioned that the use of technology like computers, video games, phones, the Internet and other is part of the daily life of the students. More importantly for this research, Villalba (2007-2008) explored the use of Web 2.0 resources in the process of teaching English and exemplified some of those tools that can be used to teach the language. For instance, the author mentioned blogs, wikis, and even podcasts that can actually serve as tools that the teachers at CEIC can use in order to promote the use of the speaking skill outside the classroom.

Motteram and Sharma (2009) discussed blended learning which refers to being in an academic learning process both in and outside a classroom with the use of technology to achieve so - in a Web 2.0 world and focused on the role that Web 2.0 technologies can play in improving language learning development in a blended world. Also, 
Motteram and Sharma (2009) made reference to the fact the technology is not going to be fully functional on its own and highlighted the importance teachers have when it comes to the creation of activities with technology. Chaves and Villalobos (2012) focused on making the students talk in the classroom on the setting of CEIC by addressing the approaches and principles used at CEIC such as the use of Cooperative Learning as well as Holistic Education to make the students learn to communicate in English.

Finally, as part of his article, Ramírez (2009) explained many benefits that using online resources have in the English learning and teaching process. He mentioned that technology has many sources of activities that can be used in order to develop the different language skills. The author exemplified them in the development of listening, pronunciation, writing and other skills of the language. This is a great example of how the use of technology can be implemented in order to improve a specific skill within an English teaching-learning setting.

\section{Theoretical Framework Technology-Enhanced Language Learning}

The use of technology has definitely become a part of the language teaching field of education. In fact, "there is a wide variety of hardware and software available for teachers of English as a Second Language (ESL) and of English as a Foreign Language (EFL)" (Zimmerman, 2009, para. 1). The TELL approach develops the idea of using technology in order enhance the process of learning and teaching a language. Moreover, the use of technology with a device that has access to the Internet "helps in motivating EFL learners to learn through authentic, challenging tasks that are interdisciplinary in nature. Such use also encourages EFL learners' active involvement with the target language and content in a real, authentic situation" (Mujtaba \& Mubarak, 2013, p.66). The TELL approach "can play a positive role in improving the quality of teaching. It can also make students interested in the course, increasing their motivation which, in turn, can help them to improve and develop their English language skills" (Moqbel \& Padmarani, 2013, p.3). Certainly, TELL has to be involved in any teaching methodology that intends to include technology as part of its principles. 


\section{Connectivism}

In a new era, society has evolved into a technology-surrounded space that people live in. Not only society, but also the way people learn, has evolved as well; in fact,

[b]ehaviorism, cognitivism, and constructivism are the three broad learning theories most often utilized in the creation of instructional environments. These theories, however, were developed in a time when learning was not impacted through technology. (Siemens, 2004, para. 1.)

Hence, there has got to be a learning theory that can relate more to what society is like nowadays, and that is Connectivism. Duke, Harper, and Johnston (2013) explained that "Connectivism is characterized as a reflection of our society that is changing rapidly. Society is more complex, connected socially, global, and mediated by increasing advancements in technology" (p.6).

In other words, the changes in society due to the rise of the technology have called for a new explanation for how people learn or "[s] tated simply, connectivism is social learning that is networked" (Duke, Harper, and Johnston, 2013, p.6). The use of technology can easily be identified as part of such learning theory. Indeed, "[i]t has also forced educators to look at what is being done in digital education and rethink, debate, and philosophize over how each part fits" (Duke, Harper, \& Johnston, 2013, p.10). Nowadays, it is important to understand that technology can, if not must, be part of the learning and teaching processes.

\section{Social Media Language Learning}

As part of the use of TELL to teach, it can be seen how some websites allow people to socialize with others. Indeed, Web 2.0 tools such as "[s]ocial Media create a new community where teachers and students do not have to communicate by means of the traditional face-to-face classroom environment. The brand-new changing way of teaching-learning environment definitely brings about impacts" (Sitthirak, 2013, para. 8). In fact, "a series of language learning social networks have popped up, and they make learning more fun, efficient, interactive and 
interesting than usual.” (Tresnick, 2010, para. 1). They are all websites that are part of the Social Media Language Learning or SMLL.

\section{Information and Communication Technologies}

Nowadays, the use of ICT in education is much more usual than it used to be many years ago. Coll, Onrubia, and Mauri (2007) explained that ICT refer to technological tools that, due to the characteristics and properties of symbolic environments that they create, can be used by students and teachers to plan, regulate and guide activities, introducing significant changes in the mental processes involved in teaching and learning. Indeed, this is a very broad idea of what the ICT can be. In fact, McDougald (2005) explained that "multimedia can be defined assimultaneous, combined use of several media at the same time such as films, slides, flashing lights and music" (p. 7). However, he also mentioned that "there is also hypermedia, which makes the internet and multimedia even more powerful in that multimedia sources are linked together. You only need to click the mouse in order to obtain the information" (Mcdougald, 2005, p. 7-8).

The use of ICT can provide many advantages if given a proper use. For example, Castro, Guzman and Casado (2007) emphasized some of the advantages of ICT for being the largest source of educational resources, allowing adaptation, providing possibilities to form groups, as well as allowing more contact with students. Moreover, the authors mentioned the fact that ICT are becoming more user friendly, accessible, and flexible tools that schools can use to improve personal and organizational performance (Castro, Guzman, \& Casado, 2007). Pizarro and Cordero (2013) mentioned the case of ICT in English teaching and pointed out that the media are interactive and collaborative. The media allow students to explore the language more creatively, to have the opportunity to access and organize information so varied, and to develop understanding of second language critically by the use of different tools that can be accessed on the Internet. Clearly, the use of tools provided as part of the ICT can create great benefits for students and teachers. 


\section{Web 2.0}

An example of ICT, or more specifically tools that the Internet provides, would be the Web 2.0. First, it is relevant to point out that there are tools offered on the Internet that are known as Web 1.0. For a better understanding, Belloch (2012) clarified that the Web 1.0 is based on the Information Society, on entertainment and passive consumption media (traditional media, radio, TV, email). The Web 1.0 pages are static and with little interaction with the user. These can be considered as the first resources that were offered online while Web 2.0 are more recent and provide more interaction. In fact, Motteram and Sharma (2009) concluded that this can be carried out with tools like "blogs and wikis, or with collaborative writing software, like Google Docs. Chat is also text and tools like MSN, or Google Talk, can be used to rehearse spoken language in writing" (p. 88).

It can be seen how there are benefits with the use of Web 2.0 tools to teach a language. In fact, Villalba (2007-2008) concluded that students are highly motivated to learn languages if they do it by using tools on the web. There are more specific Web 2.0 tools that can be used particularly for teaching speaking. For example, Ramírez (2009) explained an activity to promote speaking making use of online resources:

If teachers want their students to speak and work on their pronunciation, the following practice will meet their expectations. This exercise shows the students a dialogue that they have to record. First, they have to choose whether they want to record the man's lines or the woman's lines. After this, the computer explains how to record every single line of the conversation. Once completed, the student can listen to the conversation. For the following exercise, the students must have a microphone and speakers so that they can record themselves and listen to the dialogue. (p. 114)

Likewise, Motteram and Sharma (2009) expressed that chats can be used for not only text but also in spoken communication with tools like MSN or Skype. In fact, Motteram and Sharma stated that "[u]ntil quite recently the communication was one-to-one, but now groups can speak together" $(2009$, p. 88$)$. Besides, the authors provided another Web 2.0 tool or activity that can be used in order to practice speaking 
which is "Podcasting" (Motteram \& Sharma, 2009, p. 88). This one consists of having the students records themselves online to later share the recording to the teacher or classmates.

\section{WeSpeke}

One Web 2.0 that could allow the use of English orally with educational purposes is WeSpeke. In fact We Speke "is a growing global social network for practicing languages, sharing cultures, and making connections" (WeSpeke, 2015, para. 1). This website can definitely provide teachers and their student a platform to practice English orally out of the classroom.

\section{PodOmatic}

This website provides the Web 2.0 tool that is the podcast. In fact, PodOmatic

is the leading community of podcast producers and consumers on the Internet. Our tools streamline the highly-technical process of sharing media and make it possible for a global audience of individuals to communicate, learn, and express themselves creatively over the Internet. (PodOmatic, 2015, para. 1)

\section{Voki}

Also, the website Voki.com provides a great Web 2.0 for people to use as they best see it fit. Furthermore, "Voki is an educational tool that allows users to create their very own talking character." (Voki, 2015, para. 1). In other words, it allows its users to give the tools it a variety of uses.

\section{Methodology}

\section{Type of study}

The research paradigm that has been chosen for this investigation is the qualitative one. The choice of the qualitative paradigm is appropriate since qualitative inquiry in education consists of trying to understand what teachers and students do in the settings in which they work (Eisner, 
1998). The research was carried out with a specific population of teachers from a specific institution which made it possible to use a case study to develop such research. Baxter and Jack (2008) explained that case study is "an approach to research that facilitates exploration of a phenomenon within its context using a variety of data sources" (p. 544).

\section{Context and participants}

The population chosen for the purpose of this research included all the teachers from Centro de Estudios en Inglés Conversacional (CEIC) on the campus in Alajuela. CEIC is a project from the Universidad Nacional de Costa Rica which offers conversational courses of English to the public in general. On this campus, there is an approximate of five teachers, including the current coordinator; however, this number may vary according to the demand of the courses and student population. All these teachers are graduate students from Universidad Nacional and have at least a Bachelor's degree in English Teaching from such university. Nevertheless, some of them have a Licenciatura degree or Master's degree.

\section{Instruments}

In order to collect data for the design, implementation, and assessment of the workshop, three instruments were used. The three of them are presented below:

\section{Questionnaire for teachers}

The questionnaire (See Appendix A) consisted of a set of 12 questions in which the first four questions inquired about general information like gender, teaching experience in general and at CEIC, as well as the level they were currently teaching. The rest of the questions inquired about the information necessary for the design of the workshop, like prior knowledge on Web 2.0 tools and methodology. 


\section{Questionnaire for teachers about the workshop.}

This questionnaire (See Appendix B) consisted of 23 questions organized into four parts in order to assess different aspects of the workshop. The first part of the questionnaire asked about the design of the workshop itself, the second part is about the facilitator of the workshop, and the third part about the outcomes or results of having taken the workshop. The last part of this instrument was for the participants to share extra comments on the workshop.

\section{SWOT Analysis of the oral tasks.}

The instrument for the SWOT analysis (See Appendix C) consisted of 12 questions about the Strengths, Weaknesses, Opportunities, and Threads of three oral tasks designed taking into account the Web 2.0 tools covered in the workshop they attended. The questions were divided into each of the Web 2.0 tools, We Speke, Voki, and Pod-O-Matic.

\section{Data analysis}

The data collected were analyzed and organized accordingly based on the categories of analysis. The first and second categories were "Methodology of teachers at CEIC on Web 2.0 tools" and "Previous knowledge of teachers at CEIC on Web 2.0 tools" which make reference to the information taken into account for the design of the workshop. Then, the categories "Design of the workshop on Web 2.0 tools" and "Implementation of the workshop on Web 2.0 tools" and "Assessment of the workshop on Web 2.0 tools." refers to the workshop itself and the evaluation of the process.

\section{Procedures}

The first step to conduct this research was to carry out a literature review regarding the use of technology to teach and Web 2.0 tools among other subjects like Connectivism, Social Media Language Learning, Information and Communication Technology, and the Speaking Skill. Then, a questionnaire was applied to all the teachers at CEIC in Alajuela in order to obtain information about their methodology and 
their previous knowledge on Web 2.0 tools. Following, the workshop was designed considering the information gathered with the questionnaire. Therefore, the workshop included the training on how to sue three different Web 2.0 tools in order to promote the Speaking skill outside of the classroom. Also, there were three Oral Tasks designed so teachers could see the applicability in the Web 2.0 tools in the context of CEIC. Then, an instrument was applied in order to assess the workshop, the facilitator and the outcomes. Finally, a third questionnaire was administered for the teachers to provide an analysis on the oral tasks designed. All the information gathered was treated properly and confidentiality was assured throughout the whole process.

\section{Results and Discussion}

\section{Methodology of teachers at CEIC on Web 2.0 tools}

\section{Table 1. Activities used by CEIC teachers to promote oral production in the classroom.}

What sort of activities do you implement in order to promote oral production in the classroom?

1. Role plays, conversation in groups, games, online games.

2. Role play, debate, talk show, discussion, improvisation.

3. Pair work with speaking activities based on the unit's content, such as guessing who or what, round tables, oral presentations, board games, show me how, types of speech, games.

Note: Information taken from questionnaire applied to teachers at CEIC in Alajuela (See Appendix A).

In general, in Table 1 it can be seen how teachers who responded to the questionnaire show a consensus when it comes to the activities used. For example, the use of role-plays, conversations or discussions seem to be among the most common activities from the responses of the three teachers. Also, they include games as part of their methodology in order to promote the speaking skill in their classes. Even though they do not have the exact same responses, they do include activities under a different name but that actually have similar purposes. 


\section{Previous knowledge of teachers at CEIC on Web 2.0 tools}

\section{Table 2. CEIC teachers' view towards the of Web 2.0 tools to promote the speaking skill out of classes.}

Would you consider implementing Web 2.0 tools in order to promote the oral production of your students outside of the classroom? What is your opinion about these tools?

1. I think that is a great idea, since students attend lessons five hours per week, so it is not enough to learn English, the students should spend more hours on it.

2. Definitely. But training is required.

3. They can be used as a support to make the class more technological and creative, but the teacher still keeps been a facilitator who has to explain what the activity or the source is for.

Note: Information taken from questionnaire applied to teachers at CEIC in Alajuela (See Appendix A).

In Table 2, it is seen how the attitude of the teachers towards using different Web 2.0 tools in order to promote the speaking skill out of classes is essentially positive. They comment on how it is a great idea and how they can make classes more creative and technological. However, one of them points out that training is required.

\section{Design of the workshop on Web 2.0 tools}

Figure 1 displays how the teachers at CEIC in Alajuela felt about the workshop. It can be seen that the workshop was positive in different aspects. For example, when asked if the objective or purpose of the workshop was clear for them, they all strongly agreed. Also, they all strongly agreed that the content, that is, the Web 2.0 tools, We Speke, Voki, and Pod-O-Matic, which were included in the workshop, were both relevant and appropriate for them. The participants strongly agreed on the fact that the workshop allowed them to do things on their own, hence, stimulated their learning. 


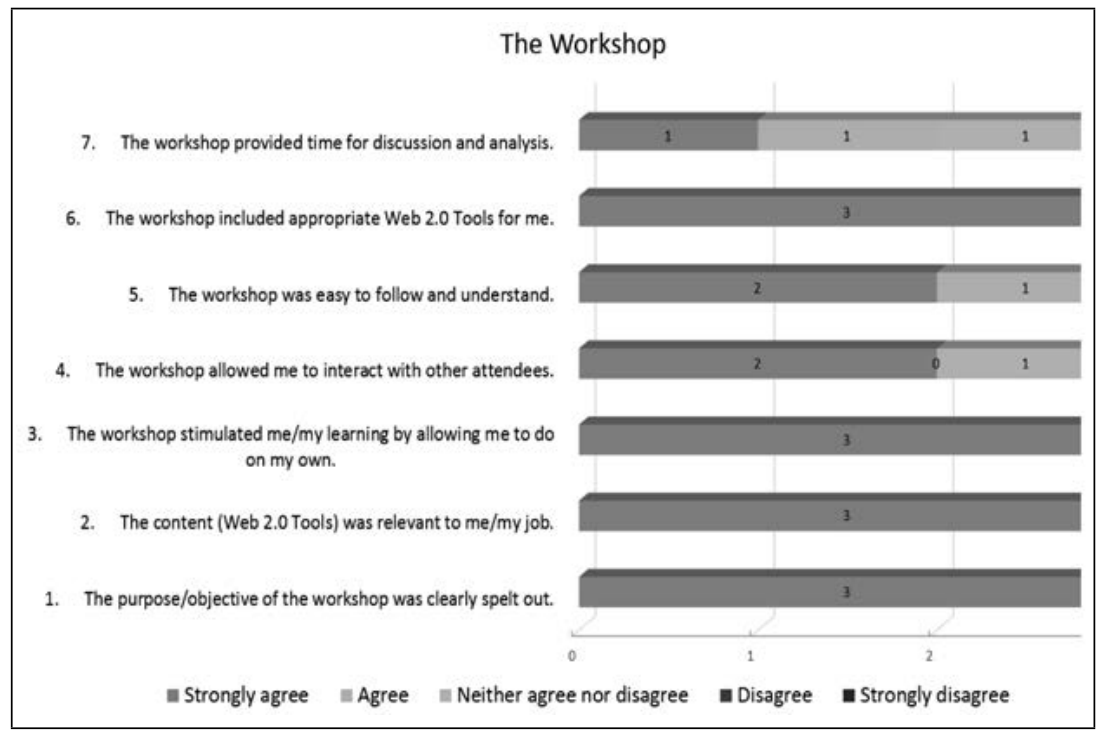

Figure 1. Evaluation of the workshop itself by the teachers at CEIC.

Note: Information taken from questionnaire applied to teachers at CEIC in Alajuela after they took the workshop (See Appendix B).

Figure 1, also shows they all strongly agreed that the content, that is, the Web 2.0 tools, We Speke, Voki, and Pod-O-Matic, which were included in the workshop, were both relevant and appropriate for them. The participants strongly agreed on the fact that the workshop allowed them to do thing on their own, hence, stimulated their learning.

\section{Implementation of the workshop on Web 2.0 tools}

Figure 2 shows how the participants of the workshop rated aspects of the performance of the facilitator. They all strongly agreed that the facilitator was both well-prepared and helpful. Also, the teachers strongly agreed on the fact that the facilitator was able to answer all the Web 2.0 tools questions and that he was able to refer to their queries appropriately. Moreover, the attendees could strongly agree that the facilitator of the workshop heard the concerns they had throughout the workshop. Another aspect the participants were able to strongly agree was that the facilitator was open to have a discussion about the content 
Workshop: Training for the Teachers of English at CEIC, in Alajuela, on Web 2.0 Tools that Can Be Used with their Students in Order to Promote the Use of English Outside of the Classroom, Focusing on the Oral

of the workshop. Indeed, the view the teachers had about the facilitator was overall positive.

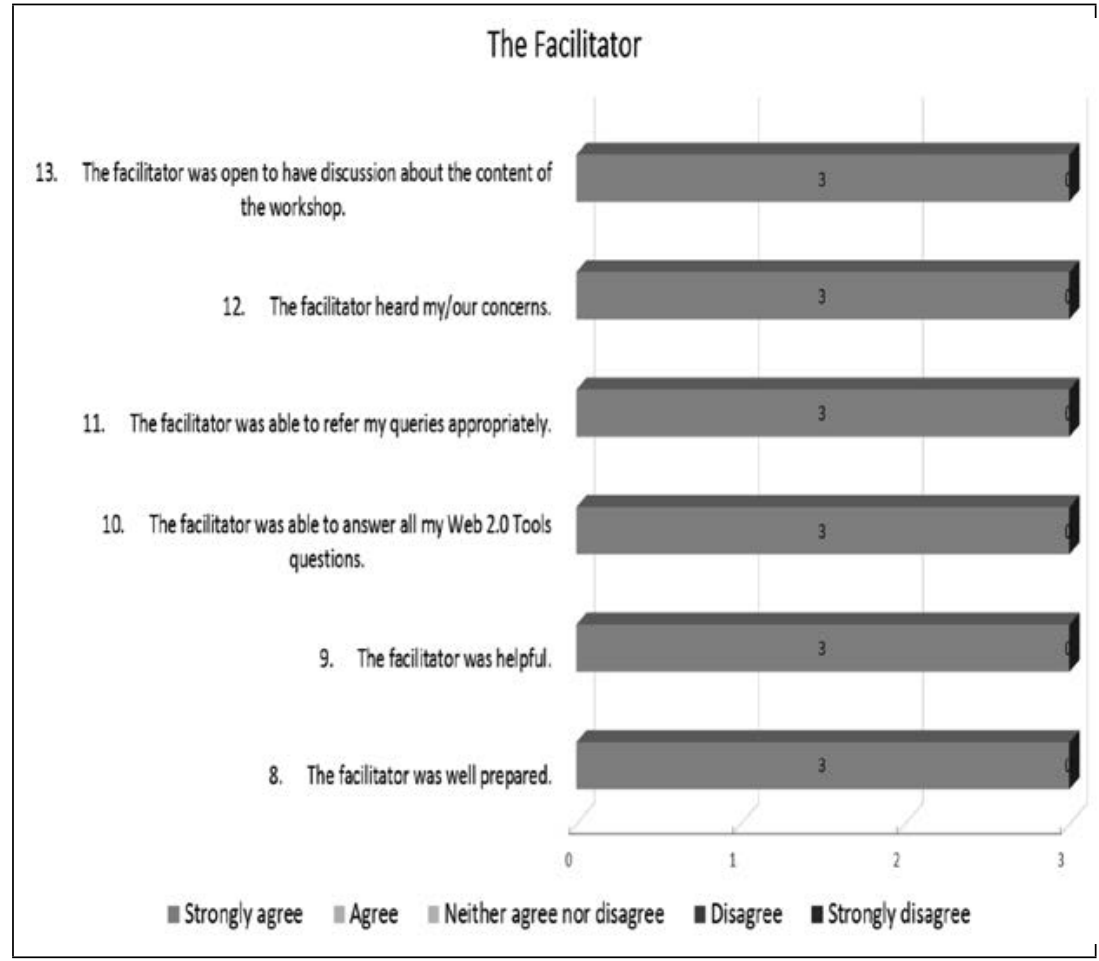

Figure 2. Evaluation of the facilitator of the workshop by the teachers at CEIC.

Note: Information taken from questionnaire applied to teachers at CEIC in Alajuela after they took the workshop (See Appendix B).

\section{Assessment of the workshop on Web 2.0 tools}

Figure 3 shows how the teacher at CEIC in Alajuela rated the outcomes of the workshop. First, all the participants either agreed or strongly agreed that the purpose of the workshop was met and that they are able to acknowledge the main uses of the Web 2.0 tools covered in the workshop. Even though they might have agreed that they can acknowledge the uses of the Web 2.0 tools, their view varies from one tool to another when it comes to using them in their context. For example, in 
the case of the We Speke, two of them could neither agree nor disagree, while one of them agreed that he or she could use it in the context they work in. Then, in the case of Voki, two of them agreed and one strongly agreed that they could use this tool in their teaching context in order to promote the speaking skill outside the classroom. On the other hand, the case of Pod-O-Matic was more divided since one disagreed, one could neither agree nor disagree, and the other disagreed. Certainly, from the three tools, the latter was the one that drew more skepticism from the participants. Nevertheless, they all agreed or strongly agreed that the workshop was a good way for them to learn about Web 2.0 Tools to promote the speaking skills outside the classroom.

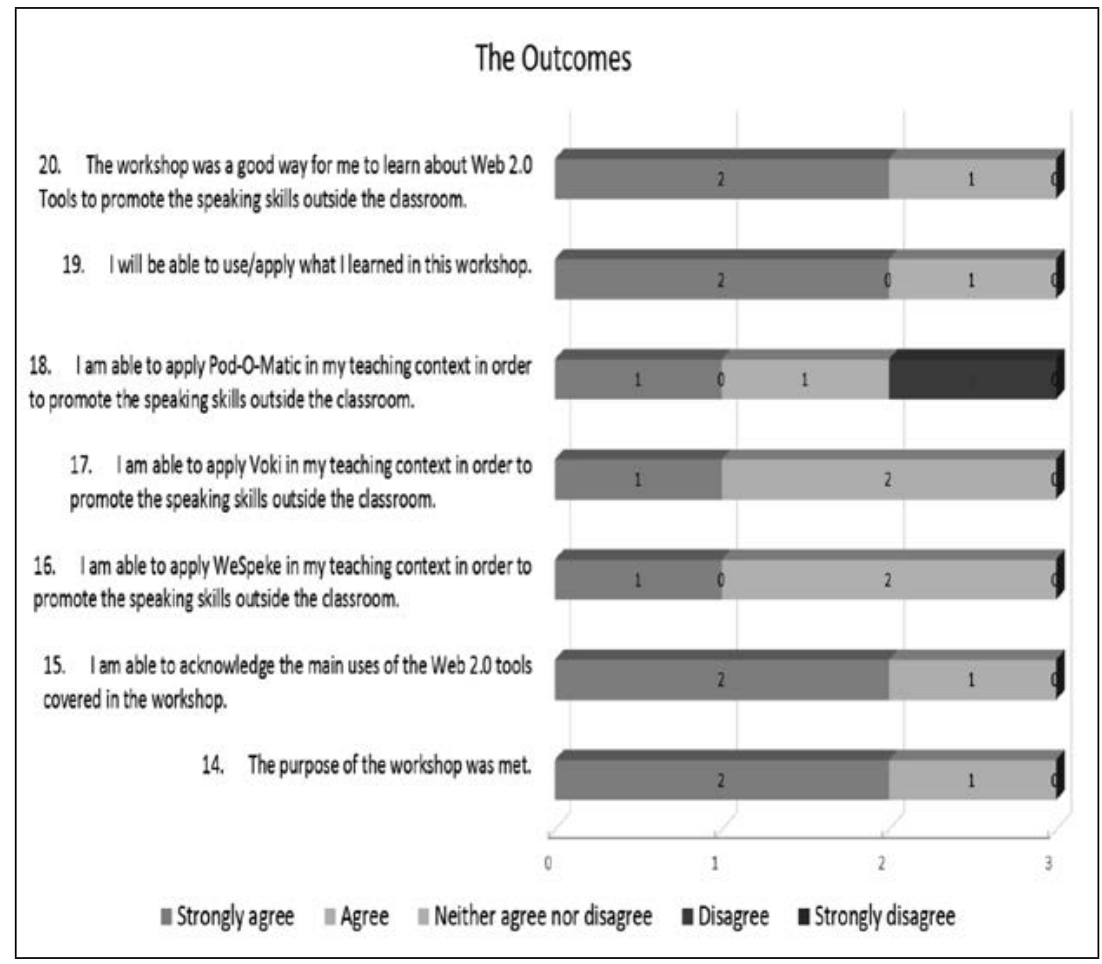

Figure 3. Evaluation of the outcomes of the workshop by the teachers at CEIC.

Note: Information taken from questionnaire applied to teachers at CEIC in Alajuela after they took the workshop (See Appendix C). 
Figure 4 shows some of the strengths of the oral tasks with the use of We Speke, Voki, and Pod-O-Matic according to the CEIC teachers. They mentioned some positive aspects like the specificity of the guidelines and how technology can be used for speaking purposes. Also, they commented on the fact that they encourage the students to have a real conversation with a native speaker and that the tools can improve communication skills. On the other hand, the teacher also pointed out some weaknesses like that the students might not know how to use them very well, but this can be solved by developing a guide for them to know how to use them properly.

Figure 4 also shows some of the opportunities that teachers at CEIC see in the oral tasks. They stated that these tools can be adapted to many different types of tasks. Also, they commented that the tools allow students to communicate with another person who could even be a native speaker, and that they also give the opportunity to the student of trying different topics at home so they can practice English. On the other hand, they also were asked to point out some threads that might affect the use of these tools and the one that stood out was the issue of having internet connection problems. They also reference that there may be other tools could be easier to use or more dynamic.

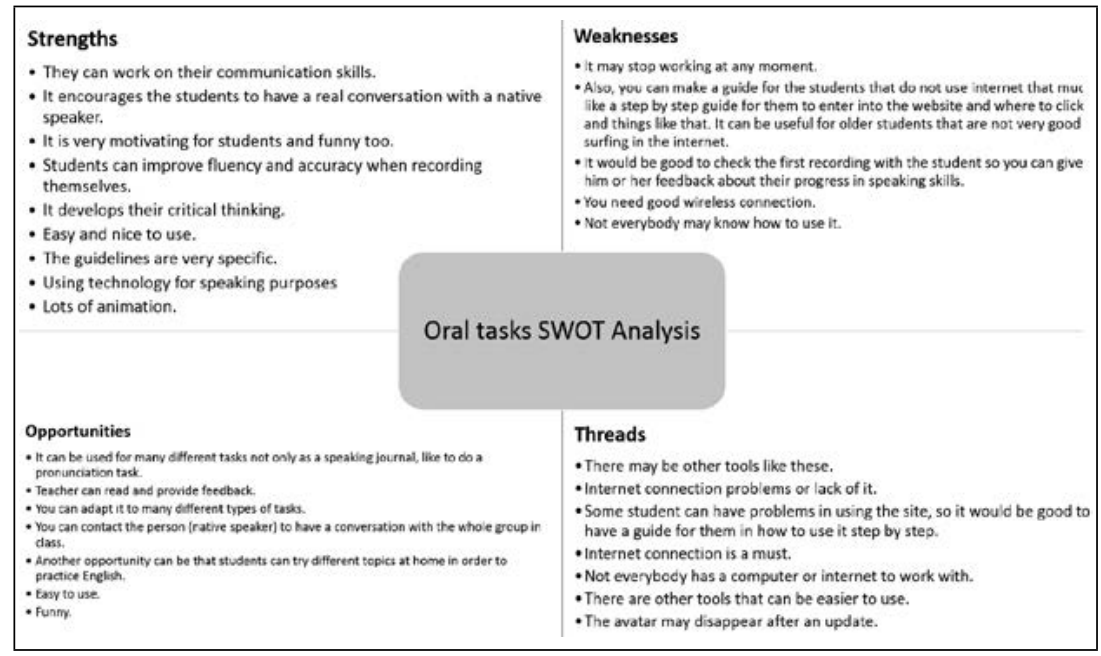

Figure 4. SWOT Analysis of the oral tasks by the teachers at CEIC.

Note: Information taken from a SWOT analysis (See Appendix C) carried out by teachers at CEIC in Alajuela of the Oral Tasks handouts (See Appendix F). 


\section{Conclusion}

When it comes to the analysis of the previous knowledge of the teacher on Web 2.0 tools and the methodology used at CEIC, it was concluded that the methodology of the teachers at CEIC usually includes activities that involve speaking. This actually has a lot to do with the fact that the nature of these courses is conversational, so they are supposed to find strategies that would allow their students to have conversations related or that would include the topic that is being covered in the classes. Regarding the knowledge teachers at CEIC have about Web 2.0 tools overall, it can be seen that they are not oblivious of the existence of some of them. Furthermore, it is possible to see how the knowledge they have about these tools is mostly theoretical, but it is not practical since they are not actually putting them into practice in their context. Fortunately, all of the teachers have a positive view towards the use of technology in English teaching. Hence, it is important to point out the fact that even though technology should be part of the methodology, it does not by any means represent a replacement of the help teachers could provide in the classes.

In order to achieve the part of the goal of this research, which was the design of a workshop in general, considering the prior knowledge of the target audience was vital so the teachers found it functional. Furthermore, being able to handle the topic of the workshop efficiently was advantageous in order to solve the attendees' queries about what was being explained in the workshop. The teachers at CEIC felt confident by having their questions answered by the facilitator of the workshop.

Based on the three specific objectives of the research, first, it was interesting to find out what the previous knowledge that all teachers at CEIC had about the Web 2.0 since it would allow to the workshop to be designed starting from the understanding they had about those tools. Second, the implementation of the workshop on Web 2.0 tools, served as a great experience for socializing opinions and knowledge among the teachers at CEIC. This experience does not happen often, but this could be a great opportunity for the rest of the teachers at CEIC to know about some Web 2.0 tools that could be used in order to promote the speaking skill of their students of the classes.

Also, another finding that brought the implementation of the workshop with the teachers was the fact that it allows other teachers to 
share their point of view about a topic. In fact, during the implementation of the workshop they were able to mention some other activities that could be carried out using the same tools that were covered in the workshop. Furthermore, they mentioned other features of the tools that were not pointed out by the facilitator. This workshop resulted in being a process really enriching for both the attendees and the facilitator.

Assessing the workshop on Web 2.0 tools, the third specific objective of the research, actually provided relevant hindsight about both the workshop and the oral tasks designed. In fact, the teachers suggested that there can be an issue about the three oral tasks with the use of this kind of tools like the possibility of having internet connection problems. Nevertheless, this served as great reflection since now it can be included as part of the diagnosis of each CEIC course to find out if the students have access to Internet.

\section{Limitations}

It is clear that time remains one of the most relevant limitations for any research project. This can be seen from the point of view of the researcher and all the possible responsibilities he might have, as well as from the point of view of time required to properly design and implement a workshop, and finally the time need for the attendees to be able to manage what is being taught in the workshop.

Another limitation when it comes to having a workshop on technological tools is the knowledge that the teachers attending might already have. This can be a limitation for two reasons; first, it may be possible that teacher already know about the tools that are being developed; and, second, there may be some teachers who are not very skillful with technology and would prefer not to take the workshop at all due to lack of confidence.

\section{Recommendations \\ To the CEIC program and coordinator.}

Assessing the current suggested evaluation strategies in the programs given out to both teachers and students so that they do not seem traditional and instead include more updated ones where the use of technology is proposed is needed. This should be done not only about the 
evaluation of the courses but the methodology as well so that the syllabi given nowadays incorporate to any extend the use of ICT as part of the teaching methodologies used in the program.

Providing training courses or workshops for the staff teachers on the use of ICT including Web 2.0 to promote the use of speaking out of classes is necessary. Indeed, having well trained teachers can increase the possibilities of having improvements in the progress of the students since they will have contact to more tools that will help them advance in their learning process.

\section{To CEIC teachers.}

Researching about tools that can be used to promote the oral skill of the students is also part of the duties of a committed teacher. In fact, training is not only responsibility of the employers since it is also part of the teachers' responsibilities to keep updating themselves when it comes to pedagogical resources and new methodologies and approaches in order to be able to improve as professionals.

Disseminating information to other colleagues should be a must in any place a teacher works, especially if teachers have knowledge that could be of great use for their peers. As a matter of fact, socializing ideas and proposals could allow improvements in a bigger scale than deciding to keep information for themselves.

\section{To future researchers.}

Considering the amount of time that would be available to develop the workshop might make a difference in the planning of such workshop. In fact, it is really important to know in advance the timeframe that would be given in order to implement the workshop and whether or not more than one session would be possible. This would prove to be helpful since it will certainly be taken into account in the organization of the workshop that might be implemented when it comes to contents and objective achievement. 


\section{References}

Baxter, P. \& Jack, S. (2008). Qualitative Case Study Methodology: Study Design and Implementation for Novice Researchers. The Qualitative Report, 13 (4), 544-559. Retrieved from http://www. nova.edu/ssss/QR/QR13-4/baxter.pdf

Belloch, C. (2012). Las tecnologías de la información y comunicación en el aprendizaje. Retrieved from http://www.uv.es/bellochc/ pedagogia/EVA1.pdf

Castro, S., Guzmán, B. \& Casado, D. (2007). Las Tic en los procesos de enseñanza y aprendizaje. Laurus, 13 (23) 213-234. Retrieved from http://www.redalyc.org/articulo.oa? id=76102311

Chaves, O. \& Villalobos, N. (2009). Let's make our students talk while sharing for learning. 1st TESOL/Applied Linguistics/Foreign Language Conference, 25, 44-559. Retrieved from http://www. una.ac.cr/bibliografia_/components/com_booklibrary/ebooks/ letsmakestudentstalk_ochaves_nvillalobos.pdf

Coll, C., Onrubia, J. \& Mauri, T. (2007). Tecnología y prácticas pedagógicas: las TIC como instrumentos de mediación de la actividad conjunta de profesores y estudiantes. Anuario de Psicología, 38(3), 377-400. Retrieved from http://www.redalyc.org/articulo. oa?id=970 17407003

Duke, B., Harper G., \& Johnston, M. (2013). Connectivism as a Digital Age Learning Theory. The International HETL Review. Retrieved from https://www.hetl.org/wp-content/uploads/2013/09/ HETLReview2013SpecialIssueArticle1.pdf

Eisner, E. W. (1998). The enlightened eye. Qualitative inquiry and the enhancement of educational practice. Chicago, IL: Prentice Hall.

McDougald, J. (2005). The Use of Modern Technology in the EFL Classroom. An Evaluation of Technology as a Tool in Language Teaching. Retrieved from http://www.academia.edu/238191/ THE_USE_OF_MODERN_TECHNOLOGY_IN_THE_EFL CLASSROOM._AN_EVAL̄UATION_OF_TECHNOLOGY AS_A_TOOL_IN_LANGUAGE_TEACHING

Moqbel, M. \& Padmarani, L. (2013). Enhancing EFL Teaching and Learning through Technology. International Journal of Social Science Tomorrow, 2(2), 1-9. 
Retrieved from https:/www.academia.edu/2629226/ Enhancing_EFL_Teaching_and_Learning_Through_Technology Motteram, G. \& Sharma, P. (2009). Blending Learning in a Web 2.0 World. International Journal of Emerging Technologies \& Society, 7 (2) 83-96. Retrieved from http://ICT'saugustine.pbworks. com/f/Blending + Learning + in $+a+W e b+2+$ World.pdf

Mujtaba, S. \& Mubarak, M. (2013). The Use of Computer Technology in EFL Classroom: Advantages and Implications. International Journal of English Language \& Translation Studies, 1(1), 61-71. Retrieved from http://eltsjournal.org/pdf_files/The $\% 20$ Use $\% 20$ of $\% 2$ 0Computer\%20Technology $\% 20$ in $\% 20$ EFL $\% 20$ Classrooms\%20Advantages \%20\%26\%20Implication-Full\%20 Paper.pdf

Pizarro, G. \& Cordero, D. (2013). ICT'S as a Technological Tool for the Development of Language Skills in Second Language University Students. Revista Electrónica Educare, 17(3), 277-292. Retrieved from http://www.revistas.una.ac.cr/index.php/EDUCARE/ articl e/view/5246/5458

PodOmatic. (2015). Company Overview. Retrieved from http://www. podomatic.com/about

Ramírez, J. (2009). Online Resources for Improving EFL Teaching and Learning. Letras, 2 (46), 103-124. Retrieved from http://www. revistas.una.ac.cr/index.php/letras/article/view/1660

Siemens, G. (2009). Connectivism: A Learning Theory for the Digital Age. Elearnspace. Retrieved from http://www.elearnspace.org/ Articles/connectivism.htm

Sitthirak, C. (2013). Social Media for Language Teaching and Learning. Retrieved from https://www.academia.edu/2612052/ Social_Media_for_Language_Teaching_and_Learning

Stepp-Greany, J. (2002). Student perceptions on language learning in a technological environment: implications for the new millennium. Language Learning \& Technology, 6 (1) 165-180. Retrieved from http://www.llt.msu.edu/vol6num1/pdf/steppgreany.pdf

Tresnick, A. (2010). 7 Social Networks Designed to Help You Learn A New Language. Retrieved from http://www.adweek.com/ socialtimes/7-social-language-learning/29269

Villalba, A. (2007-2008). Recursos de la Web 2.0 para la Enseñanza de Idioma. Varona's Institute. Retrieved from http://ced.cele. 
Workshop: Training for the Teachers of English at CEIC, in Alajuela, on Web 2.0 Tools that Can Be Used with their Students in Order to Promote the Use of English Outside of the Classroom, Focusing on the Oral Production (Speaking Skill)

unam.mx/ciberestrategias/wp-content/uploads/20 09/11/villalba_web2.pdf

Voki. (2015). About Voki. Retrieved from http://www.voki.com/about voki.php

WeSpeke. (2015). About WeSpeke. Retrieved from http://en-us.wespeke.com/about.html

Zimmerman, L. (2009). ESL/EFL Teachers and How They Use Technology. ETC Journal. Retrieved from http://etcjournal. com/2009/06/03/eslefl-teachers-and-how-they-use-technology/ 


\section{Appendix A. Instrument: Questionnaire}

Instructions: Here are a series of questions that you must completely and honestly answer.

\section{General information:}

1. Years of teaching experience

2. Years of teaching at CEIC:

3. Sex: ( ) Male ( ) Female

\section{Specific information:}

1. What levels are you currently teaching at CEIC?

2. What sort of activities do you implement in order to promote oral production in the classroom?

3. Do you think that technology can be used as a resource in the classes of conversational English? How?

4. What technological resources, websites, or tools have you used in your English conversational classes? 
5. What has been the response from the students towards the use of the technological resource you have implemented?

6. Have you ever included Web 2.0 tools (websites or software) to promote the oral production outside of the classrooms? How?

7. Do you consider that there is a balance between the use of the technology in the classroom and the use of technology outside of the classroom? Why or why not?

8. What kind of strategies or techniques have you implemented in your teaching methodology in order to promote the use of the target language orally outside of the classroom?

9. Would you consider implementing Web 2.0 tools in order to promote the oral production of your students outside of the classroom? What is your opinion about these tools?

Thank you for your time and collaboration!

Note: This data collection instrument can also be accessed online through the following link: https://docs.google.com/forms/ d/12nWLT1kbWRd_KfMq5ALznpwty7wR1MgnPobl2xNdMGQ/ viewform 


\section{Appendix B. Instrument: Questionnaire}

Instructions: Rate aspects of the workshop on a 1 to 5 scale:

$1=\quad$ "Strongly disagree," or the lowest, most negative impression

$2=$ "Disagree"

$3=\quad$ "Neither agree nor disagree," or an adequate impression

$4=$ "Agree"

$5=$ "Strongly agree," or the highest, most positive impression

Then, please answer the last three questions about personal comments about the Workshop on Web 2.0 Tools.

\begin{tabular}{|c|c|c|c|c|c|}
\hline \multicolumn{6}{|l|}{ THE WORKSHOP } \\
\hline $\begin{array}{l}\text { 1. The purpose/objective of the workshop was } \\
\text { clearly spelt out. }\end{array}$ & 1 & 2 & 3 & 4 & 5 \\
\hline $\begin{array}{l}\text { 2. The content (Web } 2.0 \text { Tools) was relevant to } \\
\text { me/my job. }\end{array}$ & 1 & 2 & 3 & 4 & 5 \\
\hline $\begin{array}{l}\text { 3. The workshop stimulated me/my learning by } \\
\text { allowing me to do on my own. }\end{array}$ & 1 & 2 & 3 & 4 & 5 \\
\hline $\begin{array}{l}\text { 4. The workshop allowed me to interact with } \\
\text { other attendees. }\end{array}$ & 1 & 2 & 3 & 4 & 5 \\
\hline $\begin{array}{l}\text { 5. The workshop was easy to follow and } \\
\text { understand. }\end{array}$ & 1 & 2 & 3 & 4 & 5 \\
\hline $\begin{array}{l}\text { 6. The workshop included appropriate Web } 2.0 \\
\text { Tools for me. }\end{array}$ & 1 & 2 & 3 & 4 & 5 \\
\hline $\begin{array}{l}\text { 7. The workshop provided time for discussion } \\
\text { and analysis. }\end{array}$ & 1 & 2 & 3 & 4 & 5 \\
\hline \multicolumn{6}{|l|}{ THE FACILITATOR } \\
\hline 8. The facilitator was well prepared. & 1 & 2 & 3 & 4 & 5 \\
\hline 9. The facilitator was helpful. & 1 & 2 & 3 & 4 & 5 \\
\hline $\begin{array}{l}\text { 10. The facilitator was able to answer all my } \\
\text { Web } 2.0 \text { Tools questions. }\end{array}$ & 1 & 2 & 3 & 4 & 5 \\
\hline $\begin{array}{l}\text { 11. The facilitator was able to refer my queries } \\
\text { appropriately. }\end{array}$ & 1 & 2 & 3 & 4 & 5 \\
\hline 12. The facilitator heard my/our concerns. & 1 & 2 & 3 & 4 & 5 \\
\hline
\end{tabular}




\begin{tabular}{|l|l|l|l|l|l|l|}
\hline $\begin{array}{l}\text { 13. The facilitator was open to have discussion } \\
\text { about the content of the workshop. }\end{array}$ & 1 & 2 & 3 & 4 & 5 \\
\hline \multicolumn{3}{|c|}{ THE OUTCOMES } \\
\hline \begin{tabular}{l} 
14. The purpose of the workshop was met. \\
\hline $\begin{array}{l}\text { 15. I am able to acknowledge the main uses of } \\
\text { the Web 2.0 tools covered in the workshop. }\end{array}$
\end{tabular} & 1 & 2 & 3 & 3 & 4 & 5 \\
\hline $\begin{array}{l}\text { 16. I am able to apply WeSpeke in my teaching } \\
\text { context in order to promote the speaking } \\
\text { skills outside the classroom. }\end{array}$ & 1 & 2 & 3 & 4 & 5 \\
\hline $\begin{array}{l}\text { 17. I am able to apply Voki in my teaching } \\
\text { context in order to promote the speaking } \\
\text { skills outside the classroom. }\end{array}$ & 1 & 2 & 3 & 4 & 5 \\
\hline $\begin{array}{l}\text { 18. I am able to apply Pod-O-Matic in my } \\
\text { teaching context in order to promote the } \\
\text { speaking skills outside the classroom. }\end{array}$ & 1 & 2 & 3 & 4 & 5 \\
\hline $\begin{array}{l}\text { 19. I will be able to use/apply what I learned in } \\
\text { this workshop. }\end{array}$ & 1 & 2 & 3 & 4 & 5 \\
\hline $\begin{array}{l}\text { 20. The workshop was a good way for me to } \\
\text { learn about Web 2.0 Tools to promote the } \\
\text { speaking skills outside the classroom. }\end{array}$ & 1 & 2 & 3 & 4 & 5 \\
\hline
\end{tabular}

21. What did you benefited the most from this workshop?

22. What did you benefited the least from this workshop?

23. What other comments would you like to add?

\section{Thank you for your time and collaboration!}

Note: This data collection instrument can also be accessed online through the following link: https://docs.google.com/forms/ d/1 Kt5xue7cBVDUa6iq3a2MCeQlcWgXqHC1iAYblRSUYvA/ viewform 


\section{Appendix C. Instrument: SWOT Analysis}

Instructions: Revise the handouts of the guidelines and rubrics of the Oral Tasks using the Web 2.0 tools We Speke, Voki, and Pod-O-Matic. Comment on the strengths, weaknesses, opportunities, and threads each of the Oral Tasks developed by the researcher.

\section{We Speke Conversation}

1. What are some of the Strengths that the We Speke Conversation oral task presents? (Consider the positive aspects or advantages you find in this specific task.) Provide at least one.

2. What are some of the Weaknesses that the We Speke Conversation oral task presents? (Consider the aspects that can be improved or avoided in this specific task) Provide at least one.

3. What are some of the Opportunities that the We Speke Conversation oral task presents? (Consider the variations or adaptation that the tool We Speke could allow.) Provide at least one.

4. What are some of the Threads that the We Speke Conversation oral task presents? (Consider the possible issues or obstacles that could be faced with the tool We Speke) Provide at least one.

\section{Voki}

5. What are some of the Strengths that the Voki oral task presents? (Consider the positive aspects or advantages you find in this specific task.) Provide at least one.

6. What are some of the Weaknesses that the Voki oral task presents? (Consider the aspects that can be improved or avoided in this specific task) Provide at least one. 
7. What are some of the Opportunities that the Voki oral task presents? (Consider the variations or adaptation that the tool Voki could allow.) Provide at least one.

8. What are some of the Threads that the Voki oral task presents? (Consider the possible issues or obstacles that could be faced with the tool Voki) Provide at least one.

\section{Pod-O-Matic Journal}

9. What are some of the Strengths that the Pod-O-Matic Journal oral task presents? (Consider the positive aspects or advantages you find in this specific task.) Provide at least one.

10. What are some of the Weaknesses that the Pod-O-Matic Journal oral task presents? (Consider the aspects that can be improved or avoided in this specific task) Provide at least one.

11. What are some of the Opportunities that the Pod-O-Matic Journal oral task presents? (Consider the variations or adaptation that the tool Pod-O-Matic could allow.) Provide at least one.

12. What are some of the Threads that the Pod-O-Matic Journal oral task presents? (Consider the possible issues or obstacles that could be faced with the tool Pod-O-Matic) Provide at least one.

\section{Thank you for your time and collaboration!}

Note: This data collection instrument can also be accessed online through the following link: https://docs.google.com/forms/ d/14wORPWLOGXk3iAJned48vkT_-IMY1q8BdsrNWg-enFE/ viewform 